\title{
Prospects for the development of industrial tourism in the Republic of Karakalpakstan
}

\section{Zhuginis DOSEKEEV1 \\ Karakalpak State University named after Berdakh}

\section{ARTICLE INFO}

\section{Article history:}

Received March 2021

Received in revised form

20 March 2021

Accepted 15 April 2021

Available online

20 May 2021

\section{Keywords:}

regions,

companies,

strategy,

tourism industry,

sources of income.

\section{ABSTRACT}

Recently, the concept of "industrial tourism" has been increasingly used in Uzbekistan as one of the most promising types of the tourism sector. Industrial tourism is becoming an important niche in the tourism industry. It is one of the many new forms of tourism that have emerged in recent decades in response to the trend of individualization and differentiation in tourism.

Studying the experience of foreign countries in the development of tourism, especially in such a direction as industrial tourism, plays an important role in the development of this direction in Uzbekistan, since those achievements and positive experience, adapted to our realities, can give a rather powerful synergistic effect in achieving the goals set before state goals for the development of the tourism sector. The article is devoted to the description of the main characteristics of industrial tourism, history and reasons for its occurrence, as well as the possible application of positive experience in the economic development of regions.

2181-1415/C) 2021 in Science LLC.

This is an open access article under the Attribution 4.0 International (CC BY 4.0) license (https://creativecommons.org/licenses/by/4.0/deed.ru)

\section{Qoraqalpoqiston Respublikasida sanoat turizmini rivojlantirish istiqbollari}

\author{
Kalit so'zlar: \\ mintaqalar, \\ kompaniyalar, \\ strategiya, \\ turizm sohasi, \\ daromad manbalari.
}

\begin{abstract}
ANNOTATSIYA
So'nggi paytlarda "sanoat turizmi" tushunchasi O'zbekistonda turizm sohasining istiqbolli turlaridan biri sifatida tobora ko'proq qo'llanilmoqda. Sanoat turizmi turizm sanoatining muhim joyiga aylanib bormoqda. Bu so'nggi o'n yilliklarda turizmda individualizatsiya va differentsiatsiya tendentsiyasiga javoban paydo bo'lgan turizmning ko'plab yangi shakllaridan biridir.
\end{abstract}

\footnotetext{
${ }^{1}$ Karakalpak State University named after Berdakh. Nukus, Uzbekistan.
} 
Turizmni rivojlantirishda, ayniqsa sanoat turizmi kabi xorijiy mamlakatlarning tajribasini o'rganish bu yo'nalishni rivojlantirishda muhim rol o'ynaydi, chunki bu yutuqlar va ijobiy tajriba bizning haqiqatlarimizga moslashgan holda, aksincha turizm sohasini rivojlantirish bo'yicha davlat maqsadlari oldiga qo'yilgan maqsadlarga erishishda kuchli sinergetik ta'sir. Maqola sanoat turizmining asosiy xususiyatlari, paydo bo'lishi tarixi va sabablarini tavsiflashga, shuningdek, mintaqalarni iqtisodiy rivojlantirishda ijobiy tajribani qo'llashga bag'ishlangan.

\section{Перспективы развития промышленного туризма Республике Каракалпакстан}

\author{
Ключевые слова: \\ регионы, \\ компании, \\ стратегия, \\ сфера туризма, \\ источники дохода.
}

\begin{abstract}
АННОТАЦИЯ
C недавних пор в Узбекистане все чаще используется понятие «промышленный туризм» как один из перспективных видов туристического сектора. Промышленный туризм становится важной нишей в индустрии туризма. Это одна из многих новых форм туризма, возникших в последние десятилетия в ответ на тенденцию индивидуализации и дифференциации в туризме
\end{abstract}

Изучение опыта зарубежных стран в развитии туризма, в особенности такого его направления, как промышленный туризм играет важную роль в развитии данного направления в Узбекистане, так как те достижения и положительный опыт, адаптированный в наши реалии, могут дать достаточно мощный синергетический эффект в достижении поставленных перед государством целей по развитию туристического сектора. Статья посвящена описанию основных характеристик промышленного туризма, истории и причин возникновения, а также возможному применению положительного опыта в экономическом развитии регионов.

Уже в 1980-х годах промышленный туризм - люди, посещающие операционные компании - был определен как растущий сегмент индустрии регионального туризма. С тех пор несколько регионов и городов открыли для себя промышленный туризм как интересный сегмент туристического рынка: среди них, например, Нагоя (Япония), Рона-Альпы (Франция), Турин (Италия), Амстердам (Нидерланды), Шанхай (Китай) и Пенсильвания (США). Это одна из многих новых форм туризма, возникших в последние десятилетия в ответ на тенденцию индивидуализации и дифференциации в туризме. Все началось с «эйфории наследия» среди (европейских) регионов в 1980-х годах. Однако постепенно регионы открыли для себя туристический потенциал действующих фирм. Британская кампания See Industry at Work обычно считается одной из первых инициатив в этой области, вдохновляя другие регионы и страны на разработку аналогичных программ. 
Есть несколько причин, почему следует развивать промышленный туризм в регионах:

1. Дополнительный источник дохода и занятости;

2. Комплексные туры по компаниям могут помочь улучшить имидж и репутацию стран, регионов и городов, а также их отраслей;

3. Инструмент кобрендинга для компаний и регионов;

4. Развитие туристической инфраструктуры;

5. Мультипликативный эффект для развития других отраслей экономики.

Для компаний прием посетителей является потенциальным источником дохода, но также и инструментом общения с заинтересованными сторонами: не только в деловом смысле, но и для подтверждения своей гражданской позиции, построения устойчивых отношений с сообществами, в которых они работают, а также для продвижения компании и ее брендов.

Можно привести массу положительных примеров по развитию промышленного туризма. Например, pecypc www.europeincoming.com выделил 10 следующих горячих точек европейского промышленного туризма:

1. Volkswagen Autostadt Factory \& Auto Museum - Вольфсбург, Германия. Посетители могут стать свидетелями полной сборки автомобиля примерно за два часа. Кроме того, есть также тематические выставки, музей ZeitHaus и впечатляющие автомобильные башни - 48-метровая стеклянная конструкция, предназначенная для хранения новых автомобилей.

2. Хранилище пива Гиннес - Дублин, Ирландия. В знаменитом магазине Storehouse, признанном ведущей европейской туристической достопримечательностью World Travel Awards, посетители могут познакомиться с историей Гиннесса, а затем насладиться дегустацией в одном из баров с потрясающими видами на горизонт Дублина.

3. Завод муранского стекла и музей Ветрарио - Мурано, Венеция, Италия. Ремесленники производят стекло на Мурано с 13 века, и несколько фабрик предлагают экскурсии и демонстрации стеклодувов, в том числе традиционный завод муранского стекла. Туристы также могут посетить Museo Vetrario - или Музей стекла - чтобы узнать об истории венецианского производства стекла, наблюдая за образцами драгоценной стеклянной посуды, относящейся к египетской эпохе.

4. Heineken Experience - Амстердам, Голландия. В интерактивном туре по бывшей пивоварне одного из крупнейших производителей пива в мире, Experience демонстрирует историю бренда, процесс пивоварения и технологические инновации, а кульминацией является посещение бара музея Heineken.

5. Parfumerie Fragonard \& Museum - Грасс, юг Франции. Построенный в 1782 году, экскурсия по исторической фабрике Фрагонар демонстрирует производство духов, посещая парфюмерные мастерские, лабораторию и винокурню. В музее представлены флаконы с ароматом и косметические реликвии, относящиеся к древним временам.

6. Cadbury World - Бирмингем, Англия. Расположенный на производственной площадке бренда Bournville мультимедийный центр демонстрирует наследие Cadbury, процессы производства и упаковки, а также сувенирный магазин и кафе, оформленное в шоколадной тематике. 
7. Музей сборки и аэроскопии Airbus - Тулуза-Бланьяк, Франция. Перед посещением музея авиации посетители могут совершить экскурсию по обширному заводу окончательной сборки Airbus, включая производственную линию крупнейшего в мире пассажирского авиалайнера А380.

8. Мир BMW - Мюнхен, Германия. На самой популярной достопримечательности Баварии посетители могут узнать об истории и будущем бренда; увидеть новейшие продукты BMW Group в ультрасовременном выставочном зале; и откройте для себя автомобильное наследие Германии в близлежащем музее.

9. Voestalpine Stahl Welt - Линц, Австрия. Новаторский производитель предлагает выставку в центре для посетителей и увлекательную экскурсию по заводу на мультимедийных автобусах, чтобы изнутри взглянуть на процесс производства стали.

10. Swarovski Crystal Worlds / Kristallwelten - Инсбрук, Австрия. Компания Swarovski's Crystal Worlds, наиболее известная производством хрустальных украшений и коллекционных предметов, помимо оптических инструментов, таких как телескопы и бинокли, а также инструментов и машин, представляет собой великолепную серию садов и палат чудес с художественными инсталляциями, вдохновленными хрусталем.

Как показывает опыт зарубежных стран, развитие промышленного туризма не требует больших затрат. Главное - определить конкурентное преимущество региона и фокусироваться на нишевых возможностях.

Республика Каракалпакстан также обладает широкими возможностями для развития промышленного туризма, но к сожалению, регионы и предприятия не пользуются данными перспективами. Основная проблема заключается в отсутствии стратегических целей и планов по этому виду туризма.

Принимая во внимание все те меры, которые осуществляются в нашей стране для развития туризма, отличными перспективами для развития промышленного туризма региона стали бы следующие направления:

1. УП «Кунградский содовый завод» (Кунградский район). Предприятие является единственным в центральноазиатском регионе, занимающийся производством кальцинированной соды.

2. Устюртский газохимический комплекс (ГХК) «Uz-Kor Gaz Chemical» (Кунградский район). Начало работы предприятия - 2016 год. В комплексе осуществляют свою деятельность заводы по производству этилена, полиэтилена и полипропилена, обеспечения энергоресурсами и разделению газа. Проект является одним из крупнейших в мире проектов в нефтегазовой сфере и получил такие награды, как: лучший проектно-финансовое соглашение в нефтехимическом и газохимическом секторах по версии международного издания «Project Finance International»; международные премии «Лучшая сделка 2012 года» изданий Trade Finance Magazine и Global Trade Review; премия «Глобальная сделка 2014 года в нефтегазовой сфере» международного издания Infrastucture Journal ;

3. Рыбоконсервный завод ГУП «MUYNOQ AKVA SANOAT» (Муйнакский район). Проект по производству рыбных консерв был запущен в декабре 2019 года. Производственная мощность - 10 млн.консерв (переработка 2,5 тыс.тонн рыбы). 
4. Текстильное предприятие «Кантекс инвест» (Канлыкульский район) по производству пряжи.

5. Узбекско-китайское совместное предприятие «Ланэкстракт» (Чимбайский район). Предприятие занимается перерабаткой солодки или лакрицы.

6. АООТ «Нукусский винзавод» (г.Нукус). Созданный в 1947 году, предприятие занимается производством ликероводочной продукции.

Конечно, вышеуказанный перечень не является исчерпывающим. Почти во всех городах и районах Республики можно выделить предприятия, к которым можно организовать туры. Главное - чтобы местные органы власти разработали план развития данного вида туризма с учетом общей стратегии развития региональной экономики.

\section{Заключение}

Понятно, что многие регионы и их отрасли заинтересованы в экономическом потенциале промышленного туризма. Есть масса аргументов для предприятий, чтобы они открывали свои двери, а для регионов - для содействия промышленному туризму, например, посредством маркетинговых мероприятий. Региональным органам власти следует провести глубокий анализ экономического воздействия данного вида туризма с целью понимания взаимозависимости между различными сегментами туристической индустрии и связи с другими отраслями и отраслями. Эти знания могут помочь как предпринимателям региона, также и самим руководителям госорганов для определения возможных векторов развития туризма. Принимая во внимание, что промышленный туризм является типичным примером туристического сегмента, в котором устанавливаются четкие связи между отраслями, развитие данного направления безусловно сделает существенный вклад в развитии регионов.

\section{БИБЛИОГРАФИЧЕСКИЕ ССЫЛКИ:}

1. A.H.J. Otgaar \& J. Klijs: The regional economic effects of industrial tourism development.

2. http://www-sre.wu.ac.at/ersa/ersaconfs/ersa10/ERSA2010finalpaper947.pdf

3. A.H.J. Otgaar: Industrial tourism. Rotterdam: Erasmus university, 2010

4. T.Churikova, A.Oshkordina: Industrial tourism as a Factor in the development of a city or region. Atlantis Press, 2020.

5. Top 10 european industrial tourism attractions: https://www. europeincoming.com/top-10-european-industrial-tourism-attractions/

6. Официальный сайт компании «Uz-Kor Gaz Chemical»: http://uzkor.com/index.php/ru/deyatelnost

7. Абдувохидов А., Қутлимуротов Ф. Экономика туризма. Т.: ТДИУ. 2007.

8. Александров А.Ю. Международный туризм. М.: Аспект Пресс. 2004.

9. Балабанов И.Т. Балабанов А.И. Экономика туризма. Учебное пособие. - М.: Финансы и статистика. 2003.

10. Гуляев В.Г. Правовое регулирование туристской деятельности. - M: Финансы и статистика. 2006. - С. 304.

11. Т.Н. Шильченко. Перспективы развития туристских кластеров в РФ. Вестник Таганрогского института управления и экономики. № 1 / 2015.

12. Кострюкоеа О.Н., Карпова Е.Г. Методы идентификации туристских кластеров в системе регионального туризма // Проблемы современной экономики. 2011. №4. 